\title{
COMPARISON OF FINANCIAL LITERACY CONCEPT IN PROJECTED CURRICULA OF SELECTED COUNTRIES
}

\author{
Karel Ševčík ${ }^{1}$ \\ ${ }^{1}$ Masaryk University, Faculty of Education, Pořričí 7/9, 63900 Brno-střed, Czech \\ Republic
}

Link to this article: https://doi.org/10.11118/lifele20211103243

Podáno: 16. 8. 2021, Přijato: 14. 12. 2021

To cite this article:ŠEVČÍK KAREL. 2021. Comparison of Financial Literacy Concept in Projected Curricula of Selected Countries. Lifelong Learning - celoživotní vzdělávání, 11 (3): 243-272.

\begin{abstract}
Due to the turbulent economic development in recent years and the rising number of financial issues individuals need to deal with, financial literacy is becoming a widely recognized concept, which, among others, spreads into the field of primary and secondary education. However, in each country, the different political, social, or cultural environment influences the final form of concept implementation. Therefore, the presented study focuses on the analysis and comparison of project curricula, which are crucial documents for financial education at the primary levels. A categorical system was presented as the main research tool, with the purpose to examine documents from the countries of the USA (Utah), Canada (Ontario), the Czech Republic and Australia. The results suggested the relative disunity of the financial literacy concept within the Ontario curriculum, as no comprehensive content block is devoted to it during the study. The concept is presented only as one of the cross-curricular topics, often lacking any continuity.
\end{abstract}


Within the Utah curriculum, the individual actions should be cognitively more demanding so that the students are properly stimulated to be active and solve the given task. The Czech curriculum then suffers from a lack of guidance in the curriculum concerning financial literacy. The cause might be in the lower scope of the document.

Keywords: educational standards, financial education, financial literacy, projected curriculum, quantitative content analysis.

Financial education is still a highly resonant topic in society, even though more than ten years have passed since the financial crisis that was one of the impulses for concept development. The urgency to bring some aspects of the financial world closer to pupils is also gaining momentum due to the turbulent economic development associated with the impact of the global epidemic of Covid 19. Because of it, individuals and countries will again have to deal with the problems of tight household budgets, indebtedness and the associated distraint, job loss, and financial security in retirement. From a longer-term perspective, there is also a transfer of responsibility for one's financial situation from country to a citizen, all under the shadow of an ever-changing financial environment bringing benefits as well as pitfalls with newly occurring financial products.

One of the ways to face such problems, or to solve them effectively, is the development of financial literacy, which has the potential to positively influence the personal financial habits of individuals in changing life situations (Cole, Paulson and Shastry, 2012). We already know that individuals who have experienced some form of financial education are better acquainted with financial issues; they are more often willing to engage in financial relationships (Yoong, 2010). Their credit behaviour (Mottola, 2015) and the decision-making in the field of pensions and management of savings improve (Nguye, Polách and Vozňáková, 2019). On the other hand, low financial literacy is often accompanied by unhealthy credit behaviour (Ottaviani and Vandone, 2017), high indebtedness and default (Artavanis and Karra, 2020). Especially younger generation aged 18-34 often face issues connected to indebtedness, arrangement of unsuitable pension savings (Lin et al., 2016) or ignore mortgage instalments (Zahirovic-Herbert, Gibler, and Chatterjee, 2016). 
The implementation of financial literacy aspects into the education context, therefore, makes sense, as evidenced by the research of Asart, Hill and Meszaros (2014), who argue that if properly designed and implemented, the curriculum itself can have a significant impact on an individual's education. However, the question for the national education policies of many countries remains the same: how to implement financial literacy in the curriculum appropriately and effectively. To find the answer, it might be beneficial to look for inspiration in countries that have long-term experience with the selected phenomenon and can be a valuable source of information. For that reason, we decided to compare the concept of financial literacy in the projected curricula of selected countries, that are often considered proficient in financial education, as they are at the forefront of international comparative rankings to determine the quality of students' knowledge in the field (OECD, 2012; OECD, 2020; Klapper, Lusardi, and Van Oudheusden, 2015) and have years of experience. This comparison should provide not only a presentation of the financial literacy concept development in the countries and their comparison but also examples of good practice and possible guidelines for more effective implementation of financial education into curricula.

Firstly, we will focus on the financial literacy definition as a complex scientific construct. Furthermore, the studies that dealt with the comparison of curricula in the field of financial literacy, and which were often the inspiration for the study, will be presented. Subsequently, the methodology used will be described together with the justification for the choice of specific countries and levels of education. Before the very conclusion and recommendations based on the analysis, the results will be presented, both of a formal and content nature of the documents.

\section{DEFINITION OF FINANCIAL LITERACY CONCEPT}

The definition of the literacy concept itself is firmly given. Literacy is not innate to the individual but formed during life in conjunction with socio-cultural factors, which, amongst others, include school and family education. It can therefore be considered a complicated, complex and at the same time variable phenomenon. Moreover, the definition of financial literacy is constantly evolving and changing, also due to the large number of institutions that try to capture it for various purposes. As a result, there 
is some disunity in the area, preventing the creation of a single, generally accepted definition.

Discussions about the benefits of financial literacy have been taking place in theoretical and empirical discourse for more than two decades. For example, in their study, Noctor, Stoney, and Stradling (1992) describe financial literacy as the ability to make effective and information-based decisions in money management. Johnson and Sherraden (2007) offer a more modern approach, operationalizing financial literacy as a skill of the practical application of financial awareness. A similar concept of financial literacy is offered by Huston (2010), according to whom financial literacy should refer not only to knowledge but also to the ability to use the acquired knowledge in real life (see also Remund, 2010). As part of the definition of financial literacy for the needs of the Canadian projected curriculum, the dimension of confidence was also assigned to knowledge and skills. Confidence refers to sufficient determination to make important and responsible decisions (Financial Consumer Agency of Canada, 2020). That is in line with the perception of financial literacy in Australia, which is based upon the definition published in the international PISA 2012 survey (Ali, Anderson, McRae and Ramsay, 2014). Financial literacy is defined there as:

... the knowledge and understanding of financial concepts, and the skills, motivation and confidence to apply such knowledge and understanding in order to make effective decisions across a range of financial contexts (OECD, 2012, p. 10)

Since we consider financial literacy to be a complex, dynamic construct, we would like to present a definition that combines the same view with the above-presented definitions. It is a construct created by Kasman, Heubareger and Hammond (2018), who wanted to capture the dynamic relationship between knowledge, skills, behaviour, social environment and other elements attributed to financial literacy (see Scheme 1).

The Foundation Skills dimension combines both cognitive skills (setting goals and strategies, discipline, self-reflection) and general skills (understanding definitions and concepts, numerical knowledge, applying basic literacy). Without these foundations, individuals would not be able to improve sufficiently in the field of financial literacy, as they would not master the basics to build on. That is also shown by the OECD research (2012), where a strong correlation of the level of financial literacy with reading 


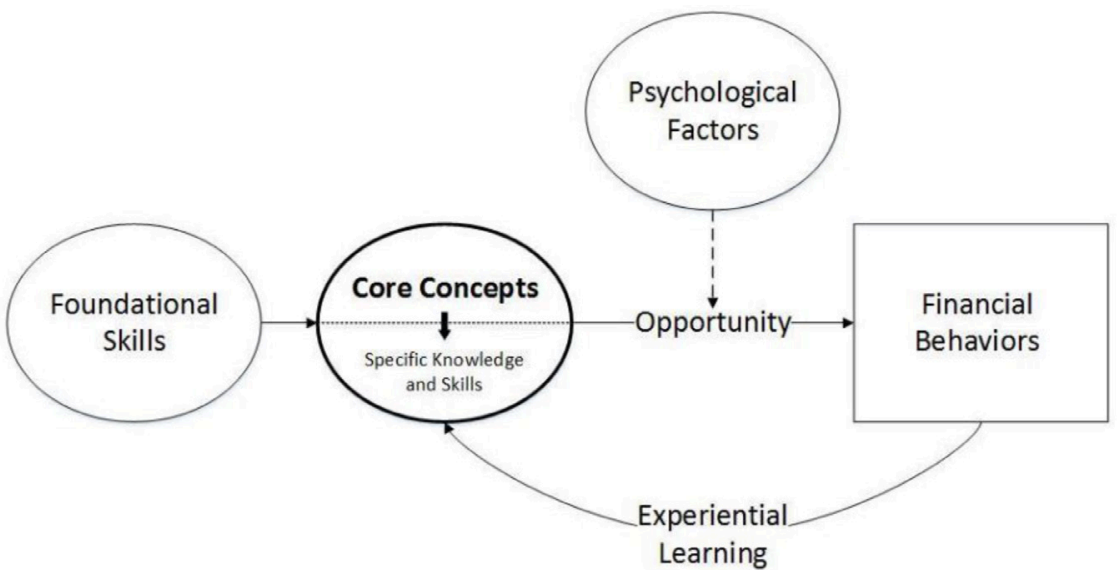

Scheme 1: Definition of the financial literacy concept (Kasman, Heubareger, and Hammond, 2018),

literacy (correlation 0.79) and mathematical ability (correlation 0.83) of the examined pupils is found. A follow-up dimension represents the Core Concepts of financial literacy. This category can be divided into knowledge and skills, thus maintaining coherence with the above definitions. For our research, this dimension is considered crucial, as it is most easily influenced by the teaching itself, and students can be then approached directly. The Core Concepts of financial literacy should have a direct impact on Financial Behaviour. As research by Hasting, Madrian and Skimmyhorn (2013) shows, there is a clear correlation between financial education and appropriate budget management, payment of liabilities, diversified portfolio management and savings. Without the reflection of knowledge into the practice and life of the individual, education, no matter how elaborate, will be unsuccessful. However, the individual must have the Opportunity to apply their knowledge and skills. That is influenced not only by the environment, culture, theavailability of products on the market but also by the country policy. As the study by Wagner and Walstad (2019) shows, especially short-term financial behaviour is influenced by the interaction with financial reality, as immediate feedback is available (e.g. we see movements at our account and its balance, overdraft notifications). However, long-term financial behaviour is more difficult to influence, so the interaction must be represented by 
the teaching itself, mediating examples from practice. The Opportunity also depends on the Psychological factors of specific individuals, such as how motivated they are, whether they have enough self-confidence to manage financial products, their approach to long-term and short-term needs. Nevertheless, the right level of self-confidence needs to be supported, because as research by Asaad (2015) shows, too much self-confidence can lead to risky operations and unhealthy financial behaviour.

The Experiential Learning link then interconnects the dimension of the Core Concepts with Financial Behaviour. Thanks to the application of the acquired information in practice, the individual often learns new knowledge or modifies the existing one, which may also cause a change in behaviour in the future. It is possible to find an example in the research of the author Agarwal et al. (2008), where adults learned from the negative experience of credit card debt, and followingly avoided similar difficulties, which resulted in repaying their debts on time. However, schools also have the opportunity to contribute to gaining experience through projects, investment games, or bank simulations. Based on the above, it is clear that the development of financial literacy is an ongoing process.

In our study, we focus primarily on the Core Concepts dimension, i.e. knowledge and skills, that are not only a common element for most definitions used but also offer a comprehensive view of financial literacy within the curriculum itself and help to grasp it.

\section{PREVIOUS STUDIES IN THE SIMILAR FIELD}

Given that the implementation of financial literacy elements in the projected curriculum of countries is a relatively modern phenomenon, there is not much research seeking to analyze this area. Most studies focus on the level of financial literacy itself, its impact on behaviour, or the possibilities of its development. Nevertheless, in the following overview, we will present those texts that dealt with the issues of curriculum innovation due to the financial education implementation.

Comparing approaches to implementing financial literacy is a relatively complex matter and is usually the domain of more extensive research rather than partial research. The initial framework is provided, for example, by the OECD document called Advancing National Strategies for Financial Education (2013), which describes the experience of G20 member countries 
with the development and implementation of national strategies for financial education. The basic strategies and characteristics of changes that have been made in the curricula of individual states in connection with the anchoring of financial education and literacy are presented.

The international project FLin€VET (Wuttke, Seifried and Schumann, 2016), the aim of which was to hold a qualitative analysis and comparison of financial literacy in the national curricula of technical schools in European countries, can also be considered a comparative analysis of the curriculum. A categorical system based on the international PISA 2012 survey was used as a research tool, in which financial literacy was viewed from the perspective of content, processes and contexts. Due to the fact that when creating the research tool, we also relied on the PISA methodology, the research provided us with valuable information about the limits of the categorical system.

Another study based in a similar field is the work of Hamburg (2009), who performed a content analysis of American mathematics textbooks for primary schools where she compared the relative representation of financial mathematical problems in textbooks and how the problems are constructed. The author proposed a comprehensive categorical system that contained three basic dimensions. Using the first dimension, the representation of different financial topics in learning tasks was analyzed, the second dimension focused on educational goals according to Bloom's taxonomy, and the last dimension aimed to reveal in which mathematical operations financial topics are applied. Melcer (2013) also dealt with the qualitative mapping of tasks with financial elements in mathematics textbooks, analyzing all Czech textbooks from 1908 to the present and finding that financial education has always played a significant role in education.

Using a similar tool as Hamburg, the authors Ševčík and Janko (2017) also tried to compare the Czech curriculum with selected foreign countries. The subject of the comparison was four financial literacy standards (Czech Republic, Australia, Japan and the United Kingdom) in order to find out what characteristics the Czech standards show in terms of the representation of basic dimensions and categories. The authors found that the compared standards differ significantly in the categories related to financial skills application. In the Czech standard, compared to foreign ones, topics leading students to reflect on financial information in authentic situations are weakened. 


\section{METHODOLOGY}

In the given chapter, the author will present the background of the research together with the main goals of the whole study. These focus mainly on the comparison of the concept of financial literacy in selected countries and on the formulation of recommendations for the practice itself. Furthermore, a research method based on quantitative data processing is presented.

\subsection{RESEARCH OBJECTIVE AND BACKGROUND}

The main goal of the study is to analyze and compare selected projected curricula aimed at compulsory school attendance in the Czech Republic, Canada (Ontario province), Australia and the USA (state Utah). That is mainly a comparison of the curricula content in terms of representation of key dimensions and categories of financial education. These are determined based on the categorical system, which was introduced in the study of Ševčík (2017) and is described below. A partial goal of the study is to pilot the system and verify its functionality.

The study focuses on the level of education within compulsory school attendance (i.e. ISCED levels 1, 2 and 3) because, in the studied countries, compulsory education is set differently, up to the age of 15-16 in the Czech Republic and Australia, while in the remaining until 18 (Utah, USA and Ontario, Canada). However, we believe that it is necessary to expand pupils knowledge and skills in the given area within the framework of compulsory school attendance so that those who decide not to continue their education are sufficiently prepared to function in the financial world. Given the current economic development and demographic trends, it can be assumed that the younger generation will not be able to learn from and be inspired by the older generation as the financial trends still evolve. They will have to rely on their own financial literacy, sufficiently developed competencies and acquired habits leading to informed decisions. However, research at the national and international levels has shown that the financial literacy level in the younger generation is currently low (Kempson, Perotti and Scott, 2013). That is the reason why it is necessary to develop the financial literacy of pupils while they are still obliged to attend school.

The primary selection criterion for the chosen countries was the fact that all of them offer many years of experience with the development of 
financial literacy, which is moreover a compulsory part of school curricula. First measures concerning financial education in those countries had been implemented long before the financial crisis of 2008 started (see chapter 4.1). Besides that, selected countries also rank among the best in international financial literacy assessments, especially Australia and Canada (see OECD, 2020; Jappelli, 2009). A secondary criterion for selection was that the mentioned countries have a developed economy and are at a comparable standard of living (according to the data of the Human Development Index). On the other hand, they are situated on three continents and underwent different political, social and economic development which might bring interesting insights as well. Moreover, the countries issued their curricular documents in languages spoken by the authors of the study.

Because it would not be possible to analyze all of Canada's provinces, as their education system and policies slightly differ, Ontario was selected as the representative. It is the largest territorial unit and had already successfully implemented financial literacy into education. Utah was then selected as the US representative because it is a state with the best-rated concept of financial literacy implementation into schools (Pelletier, 2017; Kasman, Heubareger and Hammond 2018; MoneySKILL, 2019). Therefore, it might provide examples of good practice compared to other curricula.

The project curricula of selected countries were chosen as a research sample. These can currently be considered key documents for the financial education implementation and the development of financial literacy in the school environment. They determine the required level of financial literacy at individual levels of education or offer the possibility of linking financial issues across the educational content to other areas of teaching or specific subjects. The development of the implementation in individual countries is outlined in the results part of the study.

\subsection{RESEARCH METHOD}

The main research method used was content analysis performed quantitatively. According to Krippendorff (2004), it is defined as a research technique for creating replicable and valid inferences from texts (or other meaningful things) to the contexts of their use. Simply put, it is a method of text analysis that allows texts to be related to the circumstances of the creation of their content. The methodological assumption of content analysis is 


\section{Category}

\begin{tabular}{|c|c|c|c|}
\hline \multirow{12}{*}{ 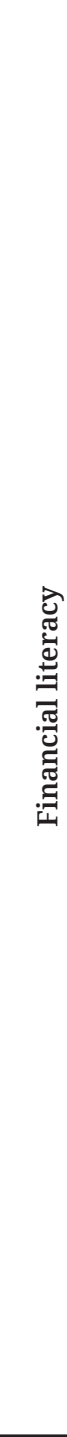 } & \multirow{6}{*}{ 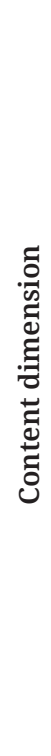 } & $\begin{array}{l}\text { Money and } \\
\text { transactions }\end{array}$ & $\begin{array}{l}\text { Meaning, form and value of money, money } \\
\text { transactions, price of goods }\end{array}$ \\
\hline & & $\begin{array}{l}\text { Financial planning } \\
\text { and management }\end{array}$ & $\begin{array}{l}\text { Incomes and expenditures of household, } \\
\text { budgeting }\end{array}$ \\
\hline & & Risk and return & $\begin{array}{l}\text { Financial risks and their prevention, } \\
\text { investments, savings, credits }\end{array}$ \\
\hline & & Work and income & $\begin{array}{l}\text { Employment and its effects, different types of } \\
\text { incomes, characteristics of own business and } \\
\text { connected factors }\end{array}$ \\
\hline & & $\begin{array}{l}\text { Financial } \\
\text { responsibility and } \\
\text { behaviour }\end{array}$ & $\begin{array}{l}\text { Consumer rights and obligations, information } \\
\text { processing }\end{array}$ \\
\hline & & $\begin{array}{l}\text { Macroeconomics } \\
\text { and microeconomics } \\
\text { aspects }\end{array}$ & $\begin{array}{l}\text { Indicators of growth and state of the } \\
\text { economy, income equality, inflation and } \\
\text { others }\end{array}$ \\
\hline & \multirow{6}{*}{ 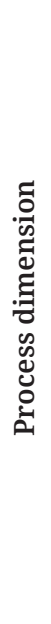 } & Remembering & $\begin{array}{l}\text { List, identify, describe, memorize, collect, } \\
\text { name, ... }\end{array}$ \\
\hline & & Understanding & $\begin{array}{l}\text { Interpret, explain, discuss, estimate, } \\
\text { understand, present, ... }\end{array}$ \\
\hline & & Applying & $\begin{array}{l}\text { Use, solve, apply, demonstrate, calculate, } \\
\text { utilize, ... }\end{array}$ \\
\hline & & Analyzing & $\begin{array}{l}\text { Observe, investigate, control, explore, } \\
\text { organize, examine, ... }\end{array}$ \\
\hline & & Evaluating & Predict, reflect, judge, defend, test, criticize, ... \\
\hline & & Creating & $\begin{array}{l}\text { Design, plan, produce, invent, develop, devise, } \\
\text {... }\end{array}$ \\
\hline
\end{tabular}


the distribution of the analyzed phenomenon into so-called units of analysis, which is to achieve, among other things, an adequate degree of reliability (Rössler, 2010). In our study, the units of analysis were the project curricula of selected countries. The coding units were then the dimensions and categories of financial literacy.

The research tool was a categorical system of Ševčík (2017), created on the basis of inductively determined categories and synthesis of knowledge from already published studies (Wuttke, Seifried and Schumann, 2016; Hamburg, 2009; Jones and Tarr 2007). When creating the categorical system, it was mainly a matter of creating a concept that would allow sufficient depth to cover not only the content/knowledge of financial education but also the process dimension, which provides insight into how the information is passed and presented to students. Thus, the individual dimensions of financial literacy were operationalized into more detailed categories, enabling to cover aspects of financial behaviour and thinking.

As part of the analysis of financial literacy curricula, the text was first coded, and the obtained data were then statistically processed using the methods of descriptive statistics. In addition to determining the absolute and relative frequencies, a chi-square test was used to verify whether the representation of individual categories and dimensions in selected standards differs significantly. Subsequently, the z-score indicator was applied, which determined a statistically significant deviation of individual categories and their expected values (see Chráska, 2016).

\section{RESULTS}

Since the purpose of the study is to present the implementation of financial literacy into curricula in a comprehensive way, first, the background of the development of the documents will be described together with the current state. Subsequently, the authors will proceed to the actual analysis and its results.

\subsection{IMPLEMENTATION OF FINANCIAL LITERACY ASPECTS INTO THE PROJECTED CURRICULA OF THE EXAMINED COUNTRIES}

Concerning the formal side, the structure of the Australian curriculum is clear and user-friendly, especially in its online form. Firstly, the focus and content 
of each educational area are described in general terms. A brief definition of the specific expected outcomes follows, for which their intersection with the key competencies of the curriculum is indicated. It is also possible to find additional resources and inspiration from other users/teachers. At the end of each year, the so-called achievement standard is presented, which sets out the knowledge and skills that the student should master after completing the given level. The document has a total of 2680 pages, so its size is considerable (Australian Curriculum, Assessment and Reporting Authority, 2016). The projected Utah curriculum is also available primarily in an online form. After selecting one of twelve education areas, it is necessary to choose a year that the user wants to focus on. Subsequently, a brief introduction for the selected level is presented, and individual Strands with specific Objectives are presented. It is also possible to see examples of the individual lesson plans, which should inspire teachers to create their own lessons or learn from other available online materials related to the issue. The number of pages is difficult to determine as the authors of the study used only the online form, but when put together, the document reached 496 pages (Utah Education Network, 2019). The Czech Framework Education Programme for Elementary Education is a 166-page document divided into nine education areas. Even before their description, however, it defines the basic education itself and the system of curricular documents related to it. Within education areas, their characteristics and goals are always described first. Then the content of individual educational areas and fields is presented using the set expected outcomes. As the document is used mainly in printed form, no additional links or explanations are available in it (Ministerstvo školství, mládeže a tělovýchovy ČR, 2017). The curricular document of Canada is on a similar basis. It is possible to display the given content either by years or by subjects. After choosing one of the options, a pdf file will be displayed, which contains an introduction to the issue, a description of basic expectations and processes leading to their fulfilment, forms of evaluation. For individual levels, general expectations are given, which are then specified (Ministry of Education, 2019).

The first country to address the implementation of financial literacy elements in the curriculum was Canada, where the Financial Consumer Agency of Canada was established in 2001 to deal with both regulatory and educational activities. The aim was primarily to provide education in the field of financial literacy to all age groups of consumers. After a series of national 
conferences on the subject, and the conduct of national surveys of the level of financial literacy within the population, the implementation of elements of financial literacy into the curriculum itself began (Financial Consumer Agency of Canada, 2020). The first document concerning financial education of adolescents in Australia was Financial literacy in schools, which mapped the current position and form of financial education not only in Australia but also in the world (Australian securities and Investments Commission, 2014). It was created by the government organization ASIC, which has the task of regulating registered companies, financial markets, and providers of financial services and credit services. According to the information obtained, the researchers suggested steps leading to the integration of the content of financial education into the national curriculum and outlined possible cooperation with organizations operating in various financial areas. Following this document, the Ministry of Education took specific measures in 2005 and issued The National Consumer and Financial Literacy Framework, the aim of which was primarily to implement the issues of financial literacy in schools (Ministerial Council on Education, Employment, Training and Youth Affairs, 2005). From the American states, Utah can be considered a pioneer in the implementation of financial literacy in the curriculum, as it established a policy in 2004 which stated that students who want to successfully complete high school must complete a financial literacy course in at least one semester. Jump\$tart coalition, which brings together experts from financial and educational institutions, governmental and non-profit organizations (OppU, 2018), played an important role in the entire implementation process. It relied mainly on statistical data showing an increase in personal bankruptcies and foreclosures in promoting the strengthening of financial literacy education. The Utah State Board of Education and Legislature have taken bold steps to empower financial and economic education. As for the Czech Republic, in 2007, financial literacy became one of the three basic pillars of the Framework Policy of the Ministry of Finance of the Czech Republic in the area of consumer protection in the financial market. For this reason, the National Strategy for Financial Education (Ministerstvo financí ČR, 2010) was prepared, which was an important conceptual document addressing the issue of strengthening the financial literacy of the population of the Czech Republic, where its pillars were mainly areas related to responsible participation in the financial market, prevention of over-indebtedness and old-age insurance. Its goal was to create a comprehensive system of financial 
education for increasing the level of financial literacy in the Czech Republic. That was followed by the issue of the document System for Building Financial Literacy in Primary and Secondary Schools (Ministerstvo financí ČR et al., 2007), in which the first standards of financial literacy were proposed, and a plan for their implementation into the Framework Educational Programs was presented.

Within Australia, the implementation of financial literacy was successfully completed in 2014, when the final version of a new national projected curriculum published by an organization called the Australian Curriculum, Assessment and Reporting Authority (Australian Curriculum,

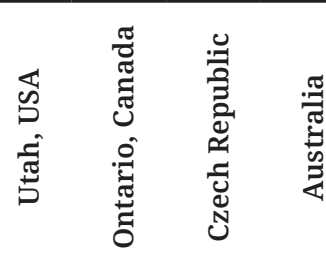

\begin{tabular}{|c|c|c|c|c|c|}
\hline \multirow{6}{*}{ 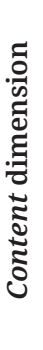 } & Money and transactions & 6 & 39 & 7 & 19 \\
\hline & Financial planning and management & 24 & 24 & 9 & 9 \\
\hline & Risk and return & 37 & 4 & 3 & 15 \\
\hline & Work and income & 21 & 12 & 0 & 54 \\
\hline & Financial responsibility and behaviour & 27 & 136 & 7 & 74 \\
\hline & Macroeconomics and microeconomics aspects & 12 & 132 & 7 & 43 \\
\hline \multirow{7}{*}{ 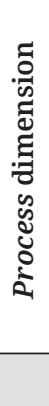 } & Remebering & 50 & 107 & 13 & 63 \\
\hline & Understanding & 50 & 70 & 7 & 41 \\
\hline & Applying & 8 & 52 & 3 & 24 \\
\hline & Analyzing & 12 & 51 & 8 & 56 \\
\hline & Evaluating & 6 & 35 & 1 & 13 \\
\hline & Creating & 1 & 32 & 1 & 17 \\
\hline & Number of outputs & 127 & 347 & 33 & 214 \\
\hline
\end{tabular}


2016) was introduced in schools. The elements of financial literacy are included in Mathematics and the newly introduced subject Economics and Entrepreneurship, which is intended for pupils aged 12 to 15 (Year 7-Year 10). Utah was the first American state to enact a financial education obligation and implement the issue into the curriculum (OppU, 2018). At present, it also has the most up-to-date curriculum of the countries surveyed, as it was revised in September 2019. The content was created mainly based on available data on the level of financial literacy in the country. Elements of financial literacy are applied in a separate subject called Financial literacy, which is designed for students in grades 11 and 12 within the K-12 curriculum (this corresponds to the age of 16-17 years, which still belongs to compulsory school attendance). Financial topics are also referred to in subjects such as Mathematics, Social Studies, and Language Arts (Utah Education Network, 2019). In the Czech Republic, the Financial Literacy Standards (Ministerstvo financí ČR et al., 2007) were included in the Framework Educational Program for Basic Education during its revision in 2013. Here, elements of financial literacy were reflected in the educational area Man and his world (age 6 to 11) and Man and Society, especially in the learning area Citizenship Education (i.e. at the age of 11-15). Both of the areas are close to the field of social studies (Ministerstvo školství, mládeže a tělovýchovy ČR, 2017). In the Czech Republic, as well as in Canada, it is not mandatory to devote a separate course to the issue. Within the Canadian curriculum, where financial literacy was included in 2011, it is possible to encounter the issue in a whole range of subjects (Mathematics, Career Studies, Social Studies, Canadian and World Studies), in which financial literacy is addressed mainly within Grades 4-8, referred to as Elementary school (equivalent to ages 9-13) (Ministry of Education, 2019). For Grades 9-12, the courses are optional, so they were not included in the analysis itself, as there is no obligation for every student to complete them.

As shown in Table II, the highest number of statements related to the development of financial literacy was identified in the Canadian curriculum. The main reason is its considerable scope and interweaving of elements of financial literacy into many areas of the curriculum. For the Utah and Australian curricula, most statements were identified in the compulsory financial literacy curriculum. In other subjects, the number of statements was rather negligible. According to the table, it is clear that the least space is devoted to the issue in the curriculum of the Czech Republic, where financial 
education is implemented only in the general area of Citizenship Education, and it does not get enough space.

\subsection{CONTENT ANALYSIS}

This section presents the main results of the study. As already mentioned in the methodological part of the text, the individual statements were first identified and then coded. As some of the curricula examined were more descriptive, every textual section beginning with a verb/act was considered a statement (e.g. compare, describe, explain, etc.). The result of the coding was then a table of absolute frequencies, which indicates the number of statements falling into the individual categories of the applied categorical system. At this stage, the authors' task was to determine whether there is a dependence between the frequencies of individual categories and the countries themselves. To determine this fact, individual hypotheses were established.

The Content dimension:

$\mathrm{H}_{0}$ : There is no dependency between the frequency of statements for the individual categories of the Content dimension.

$\mathrm{H}_{1}$ : There is a dependence (coherence) between the frequency of statements for individual categories of the Content dimension.

For the calculated number of degrees of freedom (21) and the selected levels of significance 0.05 and 0.001 , we find in the statistical tables the critical value of the test criterion $\chi 2=32.671(p<0.05)$, and $\chi 2=38.932(p<0.001)$. If we compare the calculated value of the test criterion, which was 284.9728, with the critical value, we find that the calculated value is higher, and we can thus reject the null hypothesis. Therefore, a statistically significant correlation was proved between the frequency of statements for individual categories of the Content dimension.

The Process dimension:

$\mathrm{H}_{0}$ : There is no dependency between the frequency of statements for the individual categories of the Process dimension.

$\mathrm{H}_{1}$ : There is a dependence (coherence) between the frequency of statements for individual categories of the Process dimension. 
For the calculated number of degrees of freedom (15) and for the selected levels of significance 0.05 and 0.001 , we find in the statistical tables the critical value of the test criterion $\chi 2=24.996(p<0.05)$, and $\chi 2=30.578(p<0.001)$. If we compare the calculated value of the test criterion, which was 59.03, with the critical value, we find that the calculated value is higher, and we can thus reject the null hypothesis. Therefore, a statistically significant correlation was proved between the frequency of statements for individual categories of the Process dimension.

Based on the above results, it can be stated that the distribution of statements for individual categories of the Content and Processes dimension is significantly related to the analyzed countries; there is a dependence between them.

According to Chráska (2016), when using the chi-square, i.e. The test of independence, it is often not enough just to state that there is or is not dependence between variables. We are more interested in where the addiction specifically manifests itself and how it can be interpreted. This can be achieved using the sign scheme method, which uses the z-test criterion (or z-score).

For the Content dimension, the result of testing the significance of the differences between the observed and expected frequencies is shown in Table III.

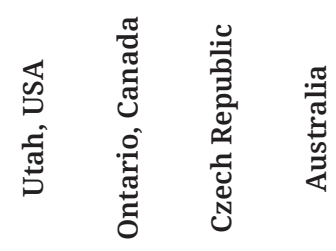

\begin{tabular}{|c|c|c|c|c|c|}
\hline \multirow{6}{*}{ 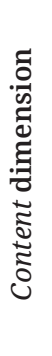 } & Money and transactions & 0 & 0 & $(+)$ & 0 \\
\hline & Financial planning and management & $(+++)$ & 0 & $(+++)$ & $(-)$ \\
\hline & Risk and return & $(+++)$ & $(-)$ & 0 & 0 \\
\hline & Work and income & 0 & $(-)$ & $(-)$ & $(+++)$ \\
\hline & Financial responsibility and behaviour & $(-)$ & 0 & 0 & 0 \\
\hline & Macroeconomics and microeconomics aspects & $(-)$ & $(+++)$ & 0 & $(-)$ \\
\hline
\end{tabular}


Table III shows that in the Utah curriculum, three of eight categories examined were more strongly represented, namely Financial planning and management, Risk and return and Work and income. Higher emphasis was also placed on the Financial responsibility and behaviour of individuals. However, the curriculum does not pay much attention to the category of Macroeconomic and microeconomic aspects, which should provide the student with an overview of general economic processes. On the contrary, the given category significantly predominates in the Canadian curriculum, nevertheless, the list ends with it, as the given curriculum lacks more statements from the areas of Risk and return, Work and income or Owning and business. The remaining examined curricula then achieve more significant deviations only in the categories of Financial planning (Czech Republic) and Owning a business (Australia). Almost the same attention is paid to the categories of Money and transactions, Price management and Financial responsibility across the sample.

Within Table IV, which summarizes the results of the z-score of the Processes dimension, the results are rather similar. The curriculum of Canada and the Czech Republic does not show any significant deviations within the given test. In the case of the Australian curriculum, there is a greater emphasis on the Analyzing process, which focuses on a more comprehensive analysis of

Table IV: z-score results for the Process dimension (own construction)

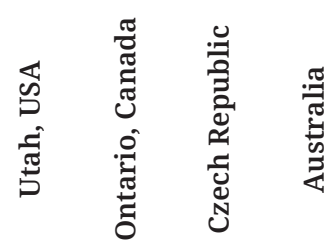

\begin{tabular}{|c|c|c|c|c|c|}
\hline \multirow{6}{*}{ 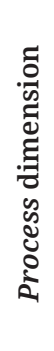 } & Remembering & 0 & 0 & 0 & 0 \\
\hline & Understanding & $(+++)$ & 0 & 0 & 0 \\
\hline & Applying & 0 & 0 & 0 & 0 \\
\hline & Analyzing & $(-)$ & 0 & 0 & $(+++)$ \\
\hline & Evaluating & 0 & 0 & 0 & 0 \\
\hline & Creating & $(-)$ & 0 & 0 & 0 \\
\hline
\end{tabular}


a task in order to better grasp it. On the other hand, the Utah curriculum tasks mainly focused on Understanding, which involves understanding the essence and meaning of information. The categories Analyzing and Creating, i.e. cognitively more demanding tasks, are slightly underestimated.

To comprehensively illustrate the results of the representation of individual categories in the analyzed standards, we present a graph of relative frequencies of statements. For the Content dimension, these frequencies are shown in Graph 1.

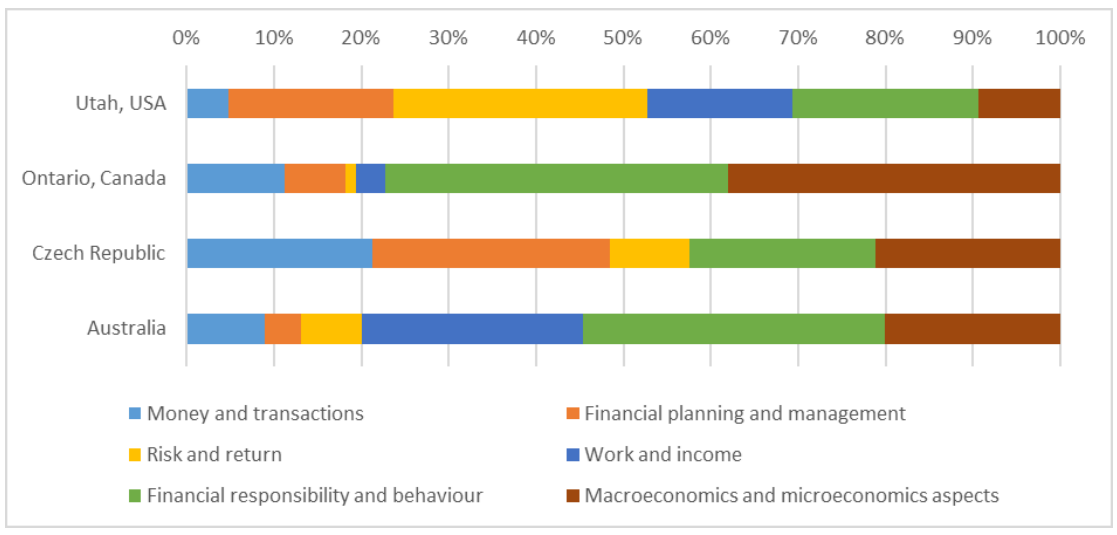

Graph 1: Relative frequencies of statements within the Content dimension (own construction)

It is clear from Graph 1 that the most strongly represented categories are Financial responsibility and behaviour and Macroeconomics and microeconomics aspects. For all standards, except Utah, they cover more than forty per cent of statements. In Utah, it is "only" 30\%, however, compared to other curricula, the Risk and return category predominates here with 29\% representation. Higher emphasis is also placed on the area of Financial Planning, which is more applied in the Czech curricular document. The categories of Money and transactions in Canada and the Czech Republic, Work and income in Utah and Owning and doing business within the Australian curriculum also exceed the 10\% threshold. Among the least represented categories in all analyzed countries are Price management 
and Owning a business (except Australia). It is also evident from the graph that except for two relatively common variables, the curriculum differs considerably in content, and each has a specific focus and emphasis.

The relative frequencies of the Process dimension (see Graph 2) can be perceived as more balanced in terms of the representation of individual categories. This fact has already been indicated in the previous z-score test.

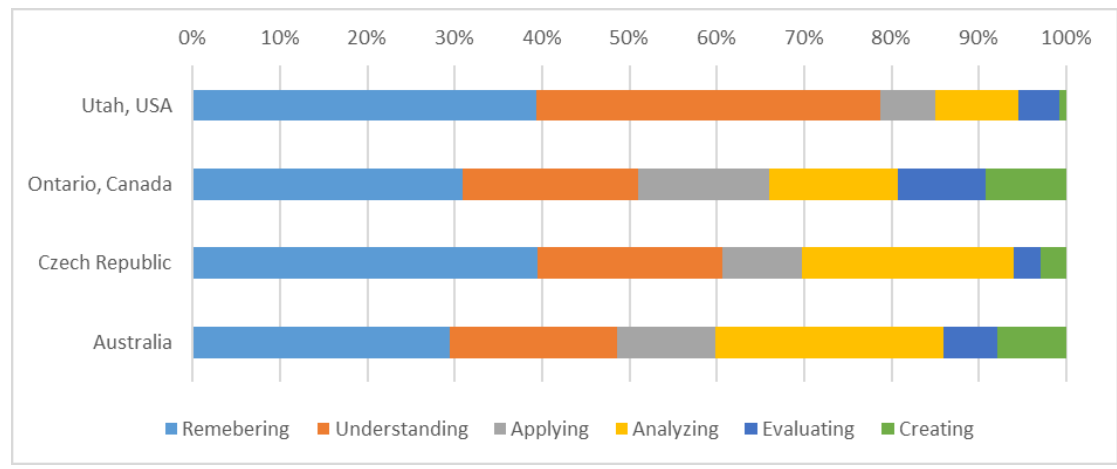

Graph 2: Relative frequencies of statements within the dimension of Processes (own construction)

Based on the graph, it can be argued that cognitively less demanding categories, i.e. Knowledge and Understanding, are significantly preferred in the standards of Utah, the Czech Republic and Ontario, where they exceed the limit of 50\%. In Australia, they are close to this limit, reaching $48 \%$. The Analyzing category is also significantly represented, especially in the Australian, Czech and Canadian curricula. The most cognitively demanding categories Evaluating and Creating are rather lagging in the curricula of the Czech Republic and Utah. In Ontario and Australia, it can be observed that the cognitively more demanding categories make up almost fifty per cent of the statements.

The smallest uniformity of the representation of categories can thus be observed especially in the Utah standard, where two categories make up almost $80 \%$ of statements. Ontario, on the other hand, excels in this respect, with Process categories relatively evenly represented. 


\section{DISCUSSION}

The aim of the study was to compare the implementation of financial literacy aspects in the projected curriculum of selected countries. The main research tool used was a categorical system looking at the perspective of financial literacy in terms of content and process dimensions, which were further divided into individual categories. In order to make the picture of the distribution of individual categories as complete as possible, the data were viewed using four different analyzes - an independence test, a table of absolute and relative frequencies, and a z-score analysis.

Based on absolute frequencies, it can be stated that the level of financial literacy implementation varies considerably from country to country. The given numbers are influenced mainly by the extent of the documents, the number of subjects where financial issues are included as a cross-curricular theme, the fact whether a separate subject is created, or the formulation of statements itself. The highest proportion of statements connected to financial literacy is in the Ontario curriculum. The main reason is the fact that the document is by far the most extensive. Although the whole curriculum is in an online form, and its overall scope is not known, we can indicate the extensiveness of the curriculum using the example of sections connected to financial literacy as they cover 332 pages. As for Australia and Utah, although both countries have a compulsory subject on financial literacy, the Australian document makes almost twice as many statements as Utah, while the curriculum is more than five times broader. That is because the individual statements in the Utah curriculum are more concise, in the form of bullets, while the individual statements in the Australian curriculum are more comprehensive and informative. The ratio comparison then works for the Czech and Utah curricula, where the Czech document is approximately three times shorter, and thus contains only a quarter of the statements concerning financial literacy itself.

After realizing that the division of statements into categories depends on countries (chi-square), the additional z-scores test pointed to a higher representation of Owning a business within the Australian curriculum, which might be explained by the important role of ASIC in developing financial literacy in the country. Such knowledge is helpful when an individual wants to start and manage their own business. It is also one of the basic pillars of 
the ASIC organization (see chapter 4.1), which was probably then reflected in the content of the curriculum. In the Czech Republic, on the other hand, the Financial planning and management category was more prominent. The reason is probably the content of the National Strategy for Financial Education, which planned clear steps to increase education in the given area. The three main pillars of the strategy for the future were responsible market participation, over-indebtedness prevention and old-age insurance. And it is the latter two threats that can be partially avoided if the consumer manages his financial affairs properly. That is one of the reasons why this higher emphasis may be placed on the given area. As far as Canada is concerned, a significant number of statements fall into the category of Macroeconomics and microeconomics aspects. Here, however, the explanation is simpler. During the analysis of individual statements, a high part of them appeared within the cross-curricular topics in the subject of History. The basic economic situation and problems of a local or global nature were presented and discussed here. Thus, they were not purely economic topics based on micro or macroeconomic variables, but rather descriptions of economies as such. That might be also viewed as the limit of the study, because such a fact is not visible at first sight from the performed analysis, and it might seem that more complicated economic structures are addressed in the given curriculum, even though this is not the case, and, it is only a description of status in the past. The Canadian curriculum also includes a noticeable representation of statements in the categories Risk and return, Work and income and Owning and business. Looking at the results of the analysis of the Utah curriculum, it is clear that there is an emphasis on the categories of Financial planning and management, Risk and return, and Work and income. As mentioned above, the need to introduce financial literacy into teaching was based primarily on statistical data of the Jump\$tart coalition showing a significant increase in citizens' bankruptcies and foreclosures. Then, when we look at the individual preferred categories, they all relate in a way to money management and planning. Therefore, it can be a response to the growing problems at the time. In contrast, statements in the Macroeconomics and microeconomics aspects category are lagging, probably because they do not play such a crucial role in personal finance management.

The z-score test was also developed for the dimension of Processes, where there are not such large differences between individual countries. In fact, all of them predominantly include less cognitively demanding 
tasks that fall into the categories of Remembering and Understanding. In the Utah curriculum, they make up almost $80 \%$ of all statements, even though cognitive development should be stressed by all academic areas of the curriculum (Gambell, 1989). In the curriculum of the Czech Republic and Australia, the category Analyzing prevails for cognitively demanding processes, which represents acts such as organizing, comparing, observing, investigating. The statements of the Canadian curriculum can be considered more evenly distributed, which might be caused by the fact that they are scattered within several cross-curricular themes into several subjects. Therefore, the assignment is different and more varied. Such diversity can then stimulate pupils to action and help to consolidate knowledge better.

The main finding is that the concept of financial literacy in the Canadian curriculum is somewhat fragmented and incoherent. It is the only surveyed country where financial literacy is not taught through a separate subject (Australia, Utah) or a comprehensive content block within the superior subject (Czech Republic). The finding corresponds with the study results of McGregor (2018), who views the approach to financial education in Canada as fragmented and inconsistent across not just subject areas and grade levels but also across provinces and regions. Even teachers themselves lack appropriate curriculum support in the field of financial literacy (Henderson, Beach and Coombs, 2021). In terms of content, two categories predominate, where the content of Financial responsibility and behaviour consists mainly of statements focused on the creation, content and impact of advertising (especially in language and art subjects), and Macroeconomics and microeconomics aspects, in which the economic situation of countries is viewed from a historical point of view (within the subject History). The basic categories focusing on the financial stability of individuals and their orientation in the financial world are neglected. We, therefore, believe that the introduction of at least a comprehensive block dedicated to the issue of financial literacy would help to convey the information more comprehensively and coherently. Nevertheless, the cross-curricular approach can still be preserved as Cordero et al. (2016) claim, as it can be even more beneficial and have more impact than separate subject implementation. Themes in other subjects would then be a suitable addition and enrichment.

As far as Utah is concerned, the individual categories of the Content dimension are more evenly represented. Only the category Price management 
is missing, focusing on the factors influencing the price, which is most likely overlooked due to the emphasis on the management of individuals' finances and the prevention of indebtedness. However, cognitively less demanding actions predominate in the Processes dimension, accounting for almost $80 \%$ of all statements. Here it is necessary to lead students to a deeper understanding of the issue because according to Luksander et al. (2014), the emphasis on the development of financial knowledge without an appropriate connection with more complex and realistic situations can lead to the fact that pupils have theoretical knowledge over practical skills.

The curriculum of the Czech Republic, where less demanding cognitive activities make up more than 60\%, also faces a similar problem. Within the Content Dimension, no space is devoted to the Work and income category. Although references to occupations can be found elsewhere in the curriculum, they are in no way linked to the financial aspects of income or employment as such. Therefore, a more comprehensive interconnection of the given areas should be offered here, in order to provide a more detailed view of the given issue. In addition, the curricular document is relatively brief (it is the narrowest in the terms of content of all the countries studied) and, thus, lacks proper guidance. However, it is not just an issue of financial literacy but other fields as well (see Habrdlová, Lupač and Vlček, 2017). As Fuchs and Zelendová (2015) say, the lower scope was intentional as it was supposed to provide schools with enough place for the creation of their original school education programme. Nevertheless, due to this fact, it does not ensure the corresponding and comparable level of knowledge of each pupil, especially in those fields included under superior subjects. Therefore, the authors recommend the enrichment of the main framework education programme especially in those fields that are not supported by the additional framework standards.

In the Australian curriculum, it can be noted that it is the only one with statements represented in all categories. It is caused by the fact that the concept of financial literacy was used in improving the research tool, i.e. The categorical system itself (see Ševčík, 2017). The authors appreciate the complexity of the curriculum, its sophisticated online form and the guidance it provides to teachers. We believe that it could serve as an example of good practice for those countries that are also considering 
the implementation of financial literacy elements in the curriculum. We also consider it appropriate to combine a separate subject devoted to the issue and specific elements included in the subject of Mathematics. Thus, a theoretical and practical approach is combined here, ensuring a more comprehensive understanding and mastery of the given area. It should develop the critical thinking of students which is seen as fundamental to effective learning and preparation to live and work in the 21st century (Ab Kadir, 2018). Besides, Attard (2018) points out that the combination of financial literacy with mathematics through practical exercises based on real-life experience might improve the engagement with mathematics and decrease pupils' anxiety towards the subject as such. Therefore, it might be viewed as beneficial for both fields.

Based on the outcomes of the comparison presented above, we would like to formulate recommendations that might be beneficial for further curricula development. Each country's curriculum is somehow specific and captures the problematics from a slightly different perspective. Therefore, it can offer a variety of best but also bad practices to learn from. Focusing on the curriculum of Canada, the implementation of financial literacy into different subjects might not bring the desired results as financial education seems then fragmented and incoherent. Especially, when the connection is left upon the teachers and proper guideline is missing. We believe that the attitude adopted by the Australian curriculum is more beneficial. There is a stand-alone subject on financial literacy interconnected with the parts implemented in the mathematics curriculum. This attitude connects the theoretical and practical knowledge and ensures higher exposure of students to the problematics. Referring to the skillset of students, it is also important to think of the balance in the cognitive demand of tasks, unlike in Utah, so students are stimulated and motivated to improve their overall financial literacy. The interactive form of the Australian curriculum offers a wide range of materials, inspiration and discussion platforms and serves as proper guidance to teachers. This higher support was missed in the Czech curriculum due to its briefness and missing additional materials. It is quite important to offer teachers space to be able to expand their teaching skills in the given area as most of them were not prepared for such implementation (Holtsch and Eberle, 2016). 


\section{LITERATURE}

Ab Kadir, M. A. (2018). An Inquiry into Critical Thinking in The Australian Curriculum: Examining Its Conceptual Understandings and Their Implications on Developing Critical Thinking as A "General Capability" on Teachers' Practice and Knowledge. Asia Pacific Journal of Education, Vol. 38, No. 4, pp. 533-549.

Agarwal, S., Driscoll, J. C., Gabaix, X. and Laibson, D. (2008). Learning in the credit card market, [Working Paper No. 13822], National Bureau of Economic Research (NBER). https://doi.org/10.3386/w13822

Ali, P., Anderson, M. E., McRae C. H., and Ramsay, I. (2014). The Financial Literacy of Young Australians: An Empirical Study and Implications for Consumer Protection and ASIC's National Financial Literacy Strategy, Company and Securities Law Journal, Vol. 32, No. 5, pp. 334-352.

Artavanis, N. and Karra, S. (2020). Financial Literacy and Student Debt', European Journal of Finance, Vol. 26, No. 4, pp. 382-401. https://doi. org/10.2139/ssrn.3327151

Asaad, C. T. (2015). Financial Literacy and Financial Behavior. Assessing Knowledge and Confidence, Financial Services Review, Vol. 24, No. 2, pp. 101-117.

Asarta, C. J., Hill, A. T., and Meszaros, B. T. (2014). The Features and Effectiveness of the Keys to Financial Success Curriculum, International Review of Economics Education, Vol. 16, pp. 39-50. https://doi.org/10.1016/j. iree.2014.07.002

Attard, C. (2018). Financial Literacy: Mathematics and Money Improving Student Engagement', Australian Primary Mathematics Classroom, Vol. 23, No. 1, pp. 9-12.

Australian Curriculum, Assessment and Reporting Authority (2016). F-10 curriculum | The Australian Curriculum, [Online], Available: https://www. australiancurriculum.edu.au/f-10-curriculum/ [12 September 2020].

Australian Securities and Investments Commission (2014). National financial literacy strategy, [Online], Available: https:/financialcapability.gov.au/files/ national-financial-literacy-strategy-2014-17.pdf [10 June 2020].

Cole, S., Paulson, A., and Shastry, G. K. (2012). Smart money: The effect of education on financial behaviour, [Working Paper No. 09-071], Harvard Business School Finance. https://doi.org/10.2139/ssrn.1317298 
Cordero, J. M., Gil, M., and Pedraja, F. (2016). Exploring the effect of financial literacy courses on student achievement: Across-country approach using PISA 2012 data, [Working Paper No. 75474], MPRA.

Financial Consumer Agency of Canada (2020). Financial literacy background, [Online], Available: https://www.canada.ca/en/financial-consumer-agency/ programs/financial-literacy/financial-literacy-history.html [5 August 2020].

Fuchs, E. and Zelendová, E. (2015). Metodické komentáre ke Standardům pro základní vzdělávání, Praha: NúV.

Gambell, T. J. (1989). Cognition, Literacy, and Curriculum. In: Leong C.K., Randhawa B.S. (eds) Understanding Literacy and Cognition. Springer, Boston, MA. https://doi.org/10.1007/978-1-4684-5748-3_15

Habrdlová, M., Lupač, M., \& Vlček, P. (2017). Srovnání obsahu vybraných kurikulárních dokumentů tělesné výchovy pro primární vzdělávání v Irsku, Nizozemsku a České republice‘. Pedagogická orientace, Vol. 27, No. 3, pp. 449-472. https://doi.org/10.5817/PedOr2017-3-449

Hamburg, M. (2009). Financialmathematical tasks in a middle schoolmathematics textbook series: A content analysis, [Dissertation work], Akron: UA.

Hastings, J. S., Madrian, B. C. and Skimmyhorn, W. S. (2013). Financial Literacy, Financial Education, and Economic Outcomes, Annual Review of Economics. Vol. 5, No. 1, pp. 347-373. https://doi.org/10.3386/w18412

Henderson, G. E., Beach, P., \& Coombs, A. (2021). Financial Literacy Education in Ontario: An Exploratory Study of Elementary Teachers' Perceptions, Attitudes, and Practices. Canadian Journal of Education/Revue canadienne de l'éducation, Vol. 44, No. 2, pp. 308-336. https://doi.org/10.53967/cje-rce. v44i2.4249

Holtsch D. and Eberle F. (2016). Teachers' Financial Literacy from a Swiss Perspective. In: Aprea C. et al. (eds) International Handbook of Financial Literacy. Springer, Singapore. https://doi.org/10.1007/978-981-10-0360-8_43

Huston, S. J. (2010). Measuring financial literacy‘, The Journal of Consumer Affairs, Vol. 44, No. 2, pp. 296-316.

Chráska, M. (2016). Metody pedagogického výzkumu: základy kvantitativního výzkumu. Praha: Grada.

Jappelli, T. (2009). Economic literacy: An International Comparison, The Economic Journal, Vol. 120, No. 548, pp. 429-451. https://doi.org/10.1111/ j.1468-0297.2010.02397.x 
Johnson, E., and Sherraden, M. S. (2007). From Financial Literacy to Financial Capability among Youth, The Journal of Sociology \& Social Welfare, Vol. 34. No. 3, pp. 119-145.

Jones, D. and Tarr, J. (2007). An Examination of the Levels of Cognitive Demand Required by Probability Tasks in Middle Grades Mathematics Textbooks, Statistics Education Research Journal, Vol. 6, No. 2, pp. 4-27.

Kasman, M., Heuberger, B., and Hammond, R. (2018) A review of large scale youth financial literacy education policies and programs, Washington: The Brookings Institution.

Kempson, E., V. Perotti P., and Scott, K. (2013). Measuring financial capability: anew instrument and results from low- and middle-income countries, Washington: International Bank for Reconstruction and Development / The World Bank. Klapper, L., Lusardi, A., and Van Oudheusden, P. (2015). Financial Literacy around the World: Insights from the Standard and Poor's Ratings Services Global Financial Literacy Survey, New York: McGraw Hill Financial.

Krippendorff, K. (2004). Reliability in Content Analysis, Human Communication Research, Vol. 30, pp. 411-433. https://doi.org/10.1111/j.1468-2958.2004. tb00738.x

Lin, J., Bumcrot, C., Ulicny, T., Lusardi, A., Mottola, G., Kieffer, C., and Walsh, G. (2016). Financial Capability in the United States 2016, Washington: FINRA Investor Education Foundation.

Luksander, A., Béres, D., Huzdik, K., and Németh, E. (2014). Analysis of the Factors that Influence the Financial Literacy of Young People Studying in Higher Education, Public Finance Quarterly, Vol. 2, pp. 220-241.

McGregor, S. L. T. (2018). Status of Consumer Education and Financial Education in Canada, Canadian Journal of Education/Revue Canadienne De l'éducation, Vol. 41, No. 2, pp. 601-632.

Melcer, M. (2013). Finanční matematika v českých učebnicích od Marchetovy reformy, [Rigorózní práce], Praha: Univerzita Karlova.

Ministerial Council on Education, Employment, Training and Youth Affairs (2005).National consumer and financialliteracy Framework, [Online], Available: http://www.curriculum.edu.au/verve/_resources/Financial_Literacy_ Framework.pdf [23 August 2020].

Ministerstvo financí ČR (2010). Národnístrategie finančního vzdělávání, [Online], Available: https://www.msmt.cz/file/31443_1_1/ [8 August 2020].

Ministerstvo financí ČR, Ministerstvo školství, mládeže a tělovýchovy ČR and Ministerstvo průmyslu a obchodu ČR (2007). Systém budování finanční 
gramotnosti v základních a středních školách, [Online], Available: https:// financnigramotnost.mfcr.cz/assets/cs/media/PSFV_System-budovanifinancni-gramotnosti-na-zakladnich-a-strednich-skolach.pdf [5 August 2020].

Ministerstvo školství, mládeže a tělovýchovy ČR (2017). Rámcový vzdělávací program pro základní vzdělávání, [Online], Available: https://www.msmt.cz/ file/43792_1_1/ [29 August 2020].

Ministry of Education (2019). A Parent's Guide to Financial Literacy in Ontario Schools, Grades 4 to 12, [Online], Available: http://www.edu.gov.on.ca/eng/ parents/financial_guide.html [5 August 2020].

MoneySKILL (2019). State Standards Interactive Map, [Online], Available: http:// afsaef.org/MoneySKILL/State-Standards-Interactive-Map [15 July 2020].

Mottola, G. (2015). The Financial Capability of Young Adults: A Generational View, Washington: FINRA Investor Education.

Nguyen, T. A. N., Polách, J. and Vozňáková, I. (2019). The Role of Financial Literacy in Retirement Investment Choice, Equilibrium: Quarterly Journal of Economics and Economic Policy, Vol. 14, No. 4, pp. 569-589. https://doi. org/10.24136/eq.2019.027

Noctor, M., Stoney, S., and Stradling, R. (1992). Financial literacy: A discussion of concepts and competences of financial literacy and opportunities for its introduction into young people's learning. London: National Foundation for Educational Research.

OECD (2012). PISA 2012 Financial Literacy Assessment Framework, [Online], Available: http://www.oecd.org/pisa/pisaproducts/46962580.pdf [30 July 2020].

OECD (2020). PISA 2018 Results (Volume IV): Are Students Smart about Money?, Paris: OECD Publishing.

OECD (2013). Advancing national strategies for financial education, [Online], Available: http://www.oecd.org/finance/financial-education/G20_OECD_NS FinancialEducation.pdf [5 August 2020].

OppU (2018). Getting an "A": Financial Literacy, [Online], Available: https:// www.opploans.com/?s=Getting+an+\%E2\%80\%9CA\%E2\%80\%9D\&post_ type=oppu [21 August 2020].

Ottaviani, C., and Vandone, D. (2017). Financial Literacy, Debt Burden and Impulsivity: A Mediation Analysis, Economic Notes, Vol. 47. No. 2-3, pp. 439-454. https://doi.org/10.1111/ecno.12115 
Pelletier, J. (2017). Is Your State Making the Grade?, Burlington: Champlain College Center for Financial Literacy.

Remund, D. L. (2010). Financial literacy explicated: The Case for a Clearer Definition in an Increasingly Complex Economy, The Journal of Consumer Affairs, Vol. 44. No. 2, pp. 276-295. https://doi.org/10.1111/j.1745-6606.20 10.01169.x

Rössler, P. (2010). Inhlatsanalyse. Konstanz: UVK Verlagsgesellschaft.

Ševčík, K. and Janko, T. (2017). Komparativní analýza standardů finanční gramotnosti v České republice a vybraných zahraničních státech, Orbis scholae, Vol. 11, No. 1, pp. 11-29. https://doi.org/10.14712/23363177.2018.55

Ševčík, K. (2017). Finanční gramotnost v projektovaném kurikulu Austrálie, Scientia in Educatione, Vol. 8, No. 1, pp. 46-64. https://doi.org/10.14712 /18047106.385

Utah Education Network (2019). Utah Core Standards, [Online], Available: https://www.uen.org/core/\#k12 [15 July 2020].

Wagner, J. and Walstad, W. B. (2019). The Effects of Financial Education on Short-Term and Long-Term Financial Behaviors, Journal of Consumer Affairs, Vol. 53, No. 1, pp. 234-259. https://doi.org/10.1111/joca.12210

Wuttke, E., Seifried, J., and Schumann, S. (Eds.) (2016). Economic Competence and Financial Literacy of Young Adults: Status and Challenges, Berlin: Verlag Barbara Budrich. https://doi.org/10.2307/j.ctvbkk29d

Yoong, J. (2010). Financial illiteracy and stock market participation: Evidence from the RAND American life panel, [Working Paper No. 2010-29], Pension Research Council. https://doi.org/10.2139/ssrn.1707523

Zahirovic-Herbert, V., Gibler, K. M. \& Chatterjee, S. (2016) Financial Literacy, Risky Mortgages, and Delinquency in the US during the Financial Crisis, International Journal of Housing Markets and Analysis, Vol. 9, No. 2. pp. 164-189. https://doi.org/10.1108/ijhma-12-2014-0060

Kontakt

Ing. Mgr. Karel Ševčík: karel.s@email.cz 